\title{
How is disability portrayed through Welsh universities' Disability Service web pages?
}

A Critical Disability Studies perspective

\author{
Beth Pickard
}

\begin{abstract}
This article explores the portrayal of disability through the Disability Service web pages of Welsh universities in order to understand their potential impression on disabled applicants. The method of Qualitative Content Analysis enables consideration of multiple dimensions including use of language, terminology and photography, as well as discussion of academic, cultural, social and logistical aspects of student life. The development of a primarily concept-driven coding frame enables consideration of the absence of certain criteria as well as the frequency and prominence of others. The ensuing discussion considers, from a Critical Disability Studies perspective, the sector's portrayal of the construct of disability. This article proposes a call to action to challenge deficit-based interpretations of disability and advocates an affirmative stance towards disability in higher education policy and practice.
\end{abstract}

KEYWORDS

ableism, access, applicant, disability, equality, higher education, Universal Design for Learning (UDL)

The conception of this article occurred organically in response to three other concurrent projects. First, and most importantly, insight was gleaned from working alongside disabled university students ${ }^{1}$ and learning of their experiences in accessing equity of provision through the application, interview, induction and study process. As is recognised by the Welsh Assembly Government (2017), the current system of applying for Disabled Students' Allowance (DSA) to finance disability assessment, diagnosis and provision is a highly complex one, which has impacted students' engagement and success 
in navigating it. As numbers of disabled students in higher education steadily increase (Gibson 2012; HESA 2018; Kendall 2016), the wider relevance of this discussion grows too.

Second, insight was gained from several recent studies and articles. A previous study, for example, reported upon the challenges that one particular cohort of students experienced (Pickard 2019a), resulting in the development of an accessible infographic for engaging with Disability Service provision at the university (Pickard and Norris 2018). Having noted these insights from first-hand experience, research was commenced to understand whether students on other courses or at other universities had shared similarly challenging experiences of understanding the process of engaging with disabilityrelated provision.

A recent article in a national newspaper further confirmed that students nationally were unaware of the mechanisms and opportunities available to make equitable study experiences possible (Butterwick 2019). This article drew from a recent national report (Johnson et al. 2019) which echoed the Welsh Assembly Government's (2017) review of the same DSA system and outlined similar flaws and challenges. Claire Johnson and colleagues (2019) suggest that two in five disabled students are not aware of the DSA funding opportunities available to them before commencing their studies. This could put them at a disadvantage in a system that is already complex and timeconsuming to access (Berg et al. 2017; Martin et al. 2019). Some 42 per cent of the disabled students consulted who were aware of DSA funding suggested that the funding was a big factor influencing their decision to apply to university. Therefore, there may be a further number of disabled students who are not getting as far as the application process because they are not aware of the funding available for specialist provision.

It is also interesting to note that there is both a decline in disabled students' awareness of DSA (62 per cent in 2015-2016 or earlier compared with 56 per cent in 2016-2017) and a decline in disabled students' satisfaction with the application process (86 per cent satisfaction in 2015-2016 or before compared with 81 per cent in 2016-2017) (Johnson et al. 2019). Students report different levels of satisfaction with DSA support, depending on whether they have physical or sensory disabilities (80 per cent), mental health conditions (73 per cent), learning difficulties/disabilities (72 per cent) or long-term health conditions (69 per cent). A compounding issue is that 'students with certain types of disability ... often found it difficult to "follow up" the support set out for them in their needs assessment letter, because of 
the nature of their condition' (Johnson et al. 2019: 11). This potentially offers some insight into the lived experience of this complex process and some arguably ableist practices which present further barriers to students' engagement (Dolmage 2017; Hutcheon and Wolbring 2012; Kerschbaum et al. 2017).

Drawing from personal experience, Caroline Butterwick (2019) suggests: 'If I had faced studying without my DSAs, I simply wouldn't have got through my course'. She also believes that 'support from before the first day will help disabled people choose higher education and continue to thrive throughout their studies'. A focus on the application and recruitment process for disabled students appears to represent a gap in the current literature. This assertion further motivated this exploration into what information is available to disabled applicants when exploring their options to apply for higher education in Wales.

The third influence upon the study is a long-held belief in an affirmative model of disability (Beckett 2015; Goodley 2017; Heydon and Iannacci 2008; Iannacci 2018) which does not see difference as deficient, and which firmly acknowledges the role of the environment, institution and wider society in disabling individuals (Rapley 2010; Steyaert 2005). There are pockets of literature exploring this perspective in higher education with rigour (Beauchamp-Pryor 2007, 2013; Bolt and Penketh 2016; Dolmage 2017; Iannacci 2018). These sources are largely from social justice (Evans et al. 2017; Liasidou 2014; Taylor and Shallish 2019) or historical perspectives (Bolt 2019; Hurst 2017). A more practical consideration of how everyday interactions, transactions, engagements and behaviours may perpetuate a medicalised and individualised interpretation of disability in Welsh higher education was of specific interest and comprises the original contribution of this article. It is proposed that the impact of the ableist university infrastructure on students' learning and sense of belonging could be key to understanding the limited recruitment and experience of disabled students in Welsh higher education.

While there are initiatives to celebrate inclusivity and diversity in the workplace such as the Athena SWAN charter (Advance HE 2019), Matrix Standard Accreditation Body (Matrix 2018) and the Disability Confident Employer scheme (Department for Work and Pensions 2018), a consideration of the institutions' more implicit perceptions of and attitudes towards disability within higher education is underexplored yet potentially highly influential. While Sharon Dobson (2019) analysed a cross-section of English university Disability Service web pages to understand the concrete provision available, 
this article seeks to analyse the positioning implicit in the language employed to convey this concrete information.

The research questions are:

- How are Welsh universities portraying the construct of disability through their Disability Service (or equivalent) ${ }^{2}$ web pages?

- What elements of students' experiences are considered and prioritised on these web pages?

- What is the implicit message on these web pages about the experience of being a disabled student in higher education?

\section{Methodology}

Authorship, positioning and (lack of) expertise

This article is written by a neurotypical, non-disabled academic who positions herself as an ally, defined by Susan Baglieri and Priya Lalvani (2019: 172) as someone who 'may use their relative positions of privilege and power to support and amplify issues of concern'. A further potential positioning is that of a stakeholder, since this discussion centres on the systemic role of the institution and its stakeholders, of which the author is one, to conceptualise and respond to the construct of disability.

This article draws on the theoretical lenses of Critical Disability Studies and DisCrit, which have evolved from the Disability Rights Movement in which disabled people are central. As the author's authority to be a voice in this discussion can be rightfully challenged, the evolution of the research project has been informed by the questions that Len Barton (1994: 10) poses to non-disabled researchers:

- What right do I have to undertake this work?

- What responsibilities arise from the privileges I have as a result of my social position?

- How can I use my knowledge and skills to challenge the forms of oppression disabled people experience and thereby help to empower them?

- Does my writing and speaking reproduce a system of domination or challenge that system?

- Have I shown respect for the disabled people I have worked with? 
In responding to these questions and seeking to ensure that the research empowers and respects disabled students and staff, I shared my findings with stakeholders. This included engaging with disabled students and staff as well as colleagues in positions of influence and power, through focus groups and presentations to relevant working groups and committees to understand whether these initial interpretations had relevance for other stakeholders. This article explores one vantage point which intentionally has a specific frame and context. Another article taking another position might extract different outcomes.

\section{Ethical considerations}

This research conformed to the ethical standards of the British Educational Research Association (BERA 2018) and the British Psychological Society's (2017) Guidelines for Internet-Mediated Research (IMR). The research was discussed with the Faculty's Ethics Champion before its commencement, who confirmed that no formal ethics application was required for this lowrisk, desk-based research study. In order that the research focusses upon the discourse within the sector rather than identifying individual universities, either in a critical or celebratory context, the analysis focusses on the sample as a whole for the duration of this article and no identifiable information is included. An anonymised table of results including the detailed results of each university, using anonymised codes rather than university names, is available on request.

\section{Ontology, epistemology and theoretical perspectives}

Critical Disability Studies is applied as a philosophy and research methodology to interpret and understand the findings from this theoretical perspective, drawing from Emma Stone and Mark Priestley's (1996) and Colin Barnes' (2003) principles for emancipatory research (see Watson 2012). Critical Disability Studies is described by Carol Thomas as 'breaking boundaries between disciplines, deconstructing professional/lay distinctions and decolonizing traditional medicalised views of disability with socio-cultural conceptions of disablism' (2007: 73). The related perspective of DisCrit analysis is also highly relevant, described by Ashley Taylor and Lauren Shallish as 'identifying the ways dominant ideologies about race and ability-neutrality permeate post-secondary education ... mak[ing] visible the problems of 
continuing narratives of fairness in higher education' (2019: 6). The application of these theoretical and methodological frameworks sought to challenge what Alan Hurst (2017) deems to be an historically atheoretical approach to disability research.

This research study aligns with an interpretivist ontology, recognising the researcher's beliefs and attitudes, as well as the cultural and social context of knowledge contributing to one of many possible interpretations of the research topic (Denzin and Lincoln 2017). A social constructionist epistemology is adopted (Burr 2015) in understanding disability as a social creation rather than representing a fixed medical condition (Rapley 2010). In addition, virtue epistemology (Fricker 2007) is explored as a general idiom in which the ethical and political aspects of epistemic conduct can be considered. A 'socially situated' (Harraway 1988, 1996) account of epistemic practice is proposed, 'such that participants are conceived not in abstraction from relations of social power . . . but operating as social types who stand in relations of power to one another' (Fricker 2007: 3). As such, the epistemic positioning and context of the findings will be deeply considered.

\section{Methodology}

A qualitative methodology was pursued in order to explore meaning in textual data available to disabled applicants on Welsh universities' Disability Service web pages. Having critically reviewed a range of methodological options, Qualitative Content Analysis (QCA) was selected as a method of data analysis in order to understand not only the frequency of particular incidences or inclusion criteria but also the potentially more implicit messages portrayed in these resources. QCA is discussed as an appropriate method for analysing how information is being expressed, thus focussing on 'latent meaning, meaning that is not immediately obvious' (Schreier 2012: 15) as well as the effects on the recipients of receiving this information (Groeben and Rustemeyer 1994).

\section{Methods and data collection}

In order to explore the information available to disabled applicants without affiliations to or enrolment in a university, and to consider the potential impact that lack of accurate information could have on student experience (Butterwick 2019) and recruitment (Johnson et al. 2019), a systematic search 
was conducted of publicly available web pages for all nine Welsh universities' Disability Services through a generic Google search using the name of the university and the term 'Disability Service'. Only open access content was included, and no data was sourced through internal processes at the researcher's university, in order to avoid bias. The data were collected and checked for consistency over a one-month period to allow for potential updating of web pages across the universities during the data collection period. A screen shot of all elements of each page was captured at the beginning and end of the one-month period to ensure reliability, as advocated by Dobson (2019). ${ }^{3}$ The final pages were collated and printed as a static object of analysis, with videos transcribed and annotated for accurate exploration.

A further level of rigour was developed to ensure that each data set was analysed in one continuous sitting and checked again in a second continuous sitting. This was to enable immersion in the data and to avoid confusion in recall between different university web pages. To achieve this immersive data analysis process, a clear timetable was developed, allocating dedicated days of analysis to each data set at a time. A reflexive log was also kept throughout to detail the researcher's responses to the immersive research process.

\section{Parameters of data collection}

In order to collate a sample of data that was comparable across universities and had defined parameters, only information contained on each university's Disability Service web page was included for analysis. Through the process of collating this data, many highly informative and relevant sources of information were found on pages of other university departments, such as Libraries, Accommodation, Careers and other professional services. It was not possible to extend the data analysis to include these sources within the scope of this study, but there is an acknowledgement that there is much rich and constructive guidance available across university web pages, beyond the Disability Service, which may offer competing or confirmatory perspectives on this discussion.

Further, there are many inclusive and enabling initiatives which do not specifically or exclusively target disabled applicants. These include various buddying and mentoring schemes, and the absence of a specific focus on disability could be seen as highly constructive and appropriate, normalising disability as part of the higher education experience. These schemes were 
also not included in the analysis, unless they were featured on the universities' Disability Service web pages.

\section{Data analysis}

A predominantly concept-driven coding frame (Schreier 2012) was developed, informed by disabled students' experiences of higher education, as reported in the literature (Abreu et al. 2016; Beauchamp-Pryor 2007, 2013; Cunnah 2015; Griful-Freixenet et al. 2017; Hong 2015; Hutcheon and Wolbring 2012; Kendall 2016; Kirby 2009; Lillywhite and Wolbring 2019; McGregor et al. 2016; Osborne 2019; Redpath et al. 2013; Riddell et al. 2007; Taylor et al. 2017; Vickerman and Blundell 2010). A Critical Disability Studies perspective (Ellis et al. 2019; Goodley 2017) on the social construction of disability (Rapley 2010) was also influential. A brief pilot of the first draft of the coding frame led to its refinement, as advocated by the method (Schreier 2012). This entailed applying the draft coding frame to one data set to explore its rigour and relevance. An accumulative, data-driven coding frame emerged, and categories from each data set were included as they arose across subsequent data sets. A final analysis was carried out including all new data-driven categories as well as the initial concept-driven categories.

The data were analysed for the frequency of occurrences in each coding category, in line with the principles of QCA (Schreier 2012). A further measure to ensure the rigour of analysis and the depth of inductive enquiry was the inclusion of each textual statement in the correlating coding category in the coding frame (see Table 1). The phrases included could then be revisited and checked across the analysis process and the raw data taken to research supervision. The frequency of phrases included in each coding category were compiled for the final collation of results and to inform the discussion section of this research study. The inclusion of frequency, central to QCA, enabled recognition of the prominence of certain dimensions and the absence of others.

The textual statements included in the coding frames were thematically analysed to understand the most prominent and significant themes in the data. On occasions, these directly correlated with the frequency of statements in particular coding categories, but at other times it was the absence of results or specific wording of less frequently found statements that was of significance. The outcomes of this thematic analysis process will shape the structure of the Discussion section. 
Table 1. Example extract of coding frame with textual statements taken directly from sources

\begin{tabular}{|c|c|c|c|}
\hline Theme & Subthemes & Indicator & Frequency \\
\hline \multirow{6}{*}{$\begin{array}{l}\text { Medical/ } \\
\text { Individual } \\
\text { Model } \\
\text { Narrative }\end{array}$} & $\begin{array}{l}\text { Focus on diagnosis/ } \\
\text { diagnostic label }\end{array}$ & $\begin{array}{l}\text { 'if you have a diagnosis of' } \\
\text { 'for students who have a } \\
\text { visual impairment' }\end{array}$ & 2 \\
\hline & $\begin{array}{l}\text { Language with } \\
\text { negative connotation } \\
\text { (e.g. 'suffers from', } \\
\text { 'struggles with', 'has } \\
\text { difficulty with') }\end{array}$ & $\begin{array}{l}\text { 'suffering with dyscalculia' } \\
\text { 'struggles with reading' } \\
\text { 'has difficulty accessing } \\
\text { lectures' }\end{array}$ & 3 \\
\hline & $\begin{array}{l}\text { Outdated language/ } \\
\text { terminology (e.g. } \\
\text { 'handicapped', } \\
\text { 'wheelchair-bound') }\end{array}$ & $\begin{array}{l}\text { 'the student is } \\
\text { wheelchair-bound' } \\
\text { 'those who are handicapped' }\end{array}$ & 2 \\
\hline & $\begin{array}{l}\text { Reference to being in } \\
\text { need of help }\end{array}$ & $\begin{array}{l}\text { 'if you require help’ } \\
\text { ‘we are here to help' }\end{array}$ & 2 \\
\hline & $\begin{array}{l}\text { Individual responsibil- } \\
\text { ity for impairment }\end{array}$ & $\begin{array}{l}\text { 'students must secure a } \\
\text { diagnosis' } \\
\text { 'students must contact the } \\
\text { centre' }\end{array}$ & 2 \\
\hline & $\begin{array}{l}\text { Hierarchical language; } \\
\text { authority; challenging } \\
\text { student as authority of } \\
\text { their own experience }\end{array}$ & $\begin{array}{l}\text { 'if there is sufficient evidence' } \\
\text { 'from a suitably qualified } \\
\text { expert' }\end{array}$ & 2 \\
\hline
\end{tabular}

\section{Intention and function of sources, legal context}

Public-facing web pages about Disability Services are intended to be informative but are also a commercial marketing tool. As is acknowledged by several authors (Nunan et al. 2005; Roberts and Hou 2016), the budgetcutting, private, fee-raising exercises within higher education in England and Wales are leading to a transactional and consumerist interpretation of higher education. Within this context, failure to deliver the provision that is advertised to students could be interpreted as a breach of the Consumer Rights Act (2015) (CMA 2015; Roberts and Hou 2016), with significant legal implications. This could lead to a disconnect between the potential richness of accessible provision largely available in reality and the reluctance to commit firmly and consistently to such opportunities on these public-facing, legally binding web pages. The Competition and Markets Authority (CMA) 
(2015, para 1.6) confirms this: 'It is important that students should receive the information necessary to make informed decisions in relation to products and services, particularly in view of the fact that they are likely to be making "one-off' decisions in respect of what and where to study'. It is acknowledged that while these web pages are public-facing and intended to be informative, there could be constrictions to the depth of information or the breadth of provision a university will commit to in this legal context.

\section{Results}

A summary of the findings of the QCA are shown below in Table 2. A fuller breakdown of sub-categories and each university's anonymised profile is available upon request.

\section{Discussion}

While there are a wealth of rich data and many perspectives that could be explored, five of the most prominent thematic findings have been selected for further discussion in response to the research questions. These were identified from the qualitative statements collated and their quantitative frequency, and they include testimonial injustice and epistemic invalidation; lack of holistic considerations; the Parsonian 'sick role'; erasure of disabled presence; and disability advantage. Each theme will be defined below and discussed with reference to the findings, before implications for policy and practice are explored.

\section{Testimonial injustice and epistemic invalidation}

Within the philosophical construct of epistemic injustice (Kidd et al. 2017), testimonial injustice (Fricker 2007) is defined by Tanya Osborne as 'where a person's account is given less credibility on the basis of their status as a knower' (2019: 233). Nancy Tuana (2006) acknowledges that it is often the dominant (non-disabled here) group who may give less value to the account of a non-dominant (disabled here) knower. Related to this concept is the notion of epistemic invalidation (Wendell 1996), whereby a person's bodily reality is denied. This is exacerbated when a student's testimony about their experience of disablement is treated as inadequate proof. Shelley Tremain critiques Miranda Fricker's (2007) original theorising around epistemic injustice 
Table 2. Frequency with which each category is seen across the sample as a whole

\begin{tabular}{|c|c|c|c|}
\hline \multicolumn{3}{|l|}{ Theme } & Total \\
\hline \multicolumn{3}{|c|}{ Medical/Individual Model narrative } & 666 \\
\hline \multicolumn{3}{|l|}{ Social Model narrative } & 358 \\
\hline \multicolumn{3}{|c|}{ Voice of disabled students } & 63 \\
\hline \multicolumn{3}{|l|}{ Legislation, policy } & 120 \\
\hline \multicolumn{3}{|c|}{ Visual representation of disability } & 65 \\
\hline \multicolumn{3}{|c|}{ Accessibility considerations } & 63 \\
\hline \multicolumn{3}{|c|}{ Travel, transport, campus } & 91 \\
\hline \multicolumn{3}{|c|}{ Provision available: Academic } & 815 \\
\hline \multicolumn{3}{|c|}{ Language that maintains the privacy of a disability, disclosure } & 78 \\
\hline \multicolumn{3}{|c|}{ Provision available: Social and cultural } & 71 \\
\hline \multicolumn{3}{|c|}{ Provision available: Well-being } & 26 \\
\hline \multicolumn{3}{|c|}{ Provision available: Accommodation } & 74 \\
\hline \multicolumn{3}{|c|}{ Provision available: Financial } & 248 \\
\hline \multicolumn{3}{|c|}{ Provision available: Application stage } & 54 \\
\hline \multicolumn{3}{|l|}{ Contact information } & 1,078 \\
\hline \multicolumn{3}{|c|}{ Reference to external information or schemes } & 130 \\
\hline \multirow[t]{7}{*}{ Photography/Imagery } & \multicolumn{2}{|c|}{ Landscape imagery } & 60 \\
\hline & \multirow[t]{4}{*}{ Figures } & Gender & \begin{tabular}{|l|}
187 female $(57 \%)$ \\
129 male $(39 \%)$ \\
14 unknown $(4 \%)$
\end{tabular} \\
\hline & & Ethnicity & \begin{tabular}{|l|}
303 White $(92 \%)$ \\
27 non-white $(8 \%)$ \\
\end{tabular} \\
\hline & & Disabled & $36(11 \%)$ \\
\hline & & Cartoon & 31 \\
\hline & \multicolumn{2}{|c|}{ University campus } & 68 \\
\hline & \multicolumn{2}{|l|}{ Objects } & 170 \\
\hline \multicolumn{3}{|c|}{ Inaccuracy/Inconsistency } & 67 \\
\hline \multicolumn{3}{|c|}{ Information for external parties other than disabled applicants } & 359 \\
\hline \multicolumn{3}{|c|}{ Information in other formats } & 31 \\
\hline \multicolumn{3}{|l|}{ Assessment } & 226 \\
\hline \multirow{3}{*}{$\begin{array}{l}\text { Specify current or } \\
\text { prospective students }\end{array}$} & \multicolumn{2}{|l|}{ Current } & 58 \\
\hline & \multirow{2}{*}{\multicolumn{2}{|c|}{ Prospective }} & 96 \\
\hline & & & 154 \\
\hline Statistics & & & 14 \\
\hline Benefits to all & & & 80 \\
\hline Access not possible, lir & ot working & & 54 \\
\hline Transition event & & & 116 \\
\hline Specialist centre & & & 113 \\
\hline Careers, employability & & & 17 \\
\hline
\end{tabular}


for not fully considering the apparatus of disability in relation to the theory, asking: 'Is the concept of epistemological ignorance itself a paradoxical and self-contradicting ableist metaphor?’ (2017: 175).

This research study aligns with Osborne's (2019) and Tremain's (2017) suggestions that the theory of epistemic injustice can be applied in a highly relevant way to current societal understanding of and engagement with the construct of disability. Both testimonial injustice and epistemic invalidation feel highly relevant to the discussion around the identity of disabled students and the information provided through these web pages which appear to accept exclusively the hierarchical knowledge of medical professionals over the insight and experiential expertise of disabled students.

Throughout the analysis of web pages, there was a significant emphasis on the need to evidence and externally validate one's disabled status. This is emphasised in the 156 phrases across the sample which emphasised the need for 'external', 'expert' or 'suitably qualified' validation of the student's disabled identity. Other studies have shown that disabled students often experience difficulty in accessing a medical diagnosis of their experience of disablement (Osborne 2019; McLean 2019). David Mitchell (2016: 11) notes that the ableist infrastructure of the institution can remain, as long as these external experts, termed 'professionals of normalisation', focus on the 'anomalies' of disabled students. The phrasing of 'suitably qualified experts' used to denote the authority to label disability mirrors the requirements of the DSA process and may be intended to enable congruence between the initial information provided to applicants and the experience of applying for and securing DSA. For example, DSA guidance confirms that students will require evidence from either a 'medical professional' or 'suitably qualified psychologist' to receive DSA. However, the implicit message behind these frequent reminders that the students' lived experience is insufficient and inadequate to achieve their status presents a strong message about the institution's conception of disability. This approach also runs counter to the Self-Advocacy and Disability Rights Movements, which emphasise that disabled people should be central to any decisions and policies that affect them (Barnes 2012; Bryan 2013; Shakespeare 2013). It also means that institutions do not learn from disabled students' lived experiences (Lillywhite and Wolbring 2019).

There are also some interesting contradictions in the language used, where several web pages acknowledge that students may not consider themselves disabled, or identify with this label, but go on to confirm that students will need to seek a medical diagnosis affirming this position (from an Individual 
Model perspective) if they wish to fully access their education. Bernadette Baker (2002) considers disability an ontological issue, before its inscription as an educational one likening this 'hunt for disability' (Campbell 2000) to a new model of eugenics that is dictated by the logic of ableism. Through the focus on naming and 'remedying' disability in educational policy and practice, the new 'eugenics of normalcy' (Fox Keller 1992) or eugenic spectre (Campbell 2000) emerges: 'Whether intended or not, is labelling a way of morphing "disability" into the assumptions of an ableist normativity . . . rather than questioning certain privileged ontologies and epistemologies to being with?' (Baker 2002: 689).

Aligning with DSA requirements, the Equality Act (2010) and other individual definitions of disability, Welsh universities' web pages are predominantly recognising disability as deficiency and as attributable to the individual by a medical expert. There is little consideration of the politics of disablement (Watson 2012), or the Social Model interpretation of disability advocated by the Welsh Assembly Government (2013). ${ }^{4}$ Nor do the web pages use the interactional interpretation of disability outlined in the Convention on the Rights of Persons with Disabilities (UN General Assembly 2006): 'Disability is an evolving concept. Disability results from the interaction between persons with impairments and attitudinal and environmental barriers that hinders their full and effective participation in society on an equal basis with others'.

Jane Seale and colleagues offer a definition of disability, which firmly recognises that it is the institution that is accountable for the students' experience of disablement: 'Disabled students are presented as oppressed victims of their universities, who are deprived of equitable access to important learning resources as a result of institutional non-compliance with legal requirements, professional codes of practice or technical standards and guidelines' (2015: 119). However, such a definition is incompatible with a system which invalidates students' testimonies and which prioritises diagnostic information that affirms a deficiency-based narrative of disability. The distance between contrasting definitions of disability evidences the impact one's understanding or portrayal of disability can have on policy, practice and lived experience.

\section{The Parsonian 'sick role'}

One of the strongest results of the analysis was the emphasis on the disabled student being dependent, reliant or in need of help (155 statements). The semantic choices of 'help' and 'support' were prevalent, and there was an 
implicit message that disabled students inevitably require 'additional' or 'specialist' support to exist, participate and thrive in higher education. This implicit message about disabled students being in need of help affirms the widely discussed stereotype of disabled people as archetypal objects of pity (Baglieri and Shapiro 2017; Brown 2014; Goodley 2017; Stramondo 2010; Tremain 2017). Examples of adherence to the Medical/Individual Model of Disability found in 666 statements also encapsulate this perspective, emphasising disability as residing within the individual and being firmly the individual's responsibility ( 93 statements).

This is perhaps unsurprising, as the Equality Act (2010), to which universities must comply, perpetuates this Individual Model, essentially instructing institutions to administer services and 'reasonable adjustments' as compensation for deficit. This further conflates disability with deficiency and with difference from the normed archetype of higher education. This firm suggestion that disabled students will inevitably be dependent and require help and support in order to thrive in higher education echoes Talcott Parsons' (1951) legitimation of the 'sick-role' through medical power (Scambler 2012). Parsonian medical sociology was widely accepted as an historically adequate account of normative expectations around illness in mid-twentieth century capitalist society (Varul 2010). The Parsonian paradigm equated illness with deviance, seeing it as dysfunctional, and considered the impact of such deviance on the social system. The 'sick role' was to be seen as 'abhorrent and undesirable', and in order for the individual to regain their 'full human status' they were expected to be responsible for seeking help from medical experts (Parsons 1951).

While the ideology of the sick role is still prevalent in society and arguably in institutional dynamics, Mike Oliver (2017) offers several critiques of this widely applied and accepted ideology in relation to disability. Parsonian medical sociology is highly determinist, with behaviour only viewed positively if it is 'commensurate with professionals' perceptions of reality' (2017: 21). Additionally, it ignores political, social and economic considerations of individual situations, as well as undermining and denying the subjective interpretation of impairment from the individual's perspective. From a Critical Disability Studies perspective, this ideology also does not separate impairment from disability (Anastasiou and Kauffman 2013; Dolmage 2017) and assumes illness and disability to be synonymous.

The binary separation between disabled students who will be in need of help and non-disabled students who might not be is a reductionist simplifica- 
tion. The over-emphasis on aspiring for independence is also an inaccurate reflection of non-disabled students' experiences of university (Martin et al. 2019; Morgan 2012). It is reminiscent of Rosi Braidotti's (2013) post-humanist critique of the over-emphasis humanism places upon independence and autonomy, as applied in a disability studies context by Dan Goodley and colleagues (2014). There are several statements which make broad overgeneralisations about disabled students solely based on diagnosis, such as the suggestion that students with mental health challenges may feel unsure what is expected of them or how to organise their time effectively. One source offered guidance to students 'suffering from a visual impairment', while another referenced 'problems keeping up' due to a diagnosis of dyslexia, and strategies for 'circumventing dysgraphic problems' (italics added). Each of these examples firmly positions the 'problem' of disability as residing firmly within the disabled student and assumes a disability-negative ontology (Baker 2002). There are also some inaccuracies and many over-simplifications. Overall, there is a lack of recognition of the individual variations between unique students who are disabled by diverse factors and barriers, some institutional and systemic.

In order to access equitable educational provision, students are required to actively apply to the notion of the 'sick role', which ascribes them with professional, medical 'help' to engage in a largely ableist system. The information presented to applicants and the general public confirms that disabled students will need 'support' and that to access this support they will need to confirm their identification as dependent and in need of help. This compounding system 'is the product of the psychological imagination constructed upon a bedrock of non-disabled assumptions of what it is like to experience impairment' (Oliver 2017: 21); it fails to see illness and disability as conceptually distinct. Further, it is possible that, in view of Ian Hacking's (1995) theory of 'looping effects', disabled students may in turn change their self-understanding and self-perceptions to align with how they are perceived and classified by the university and by society (Hjörne and Säljö 2014), experiencing internalised ableism (Kumari Campbell 2009) as a result.

\section{Lack of holistic considerations}

The findings in Figure 2 demonstrate a significant emphasis on academic (815 statements) and financial (248 statements) dimensions of university study, with much less consideration of social (71 statements) and logistical 
considerations (the application process $=54$ statements, transition to university $=116$ statements, travel $=91$ statements). In the sample, as in the wider literature, there was a surprising lack of consideration of the accessibility of the application and recruitment process. Nancy Evans and colleagues (2017) and Karen Myers and colleagues (2014) are amongst the few sources to briefly discuss this dimension, although in an American context. There is also surprisingly little reference to well-being provision (26 statements), despite a potential correlation or co-existence of disabled identity and mental health challenges (Aitken et al. 2017). The stakeholders involved in this process officially interpret mental health challenges as a form of disability (Equality Act 2010).

It is understood that this also likely reflects the alignment between these web pages and the exclusively academic provision the DSA will fund, although this is not explicitly stated. However, if these pages are to represent access considerations for disabled applicants, a bleak picture is painted of the potential to engage accessibly with cultural, social and other holistic elements of the student experience, which have been highlighted by many as central to student life (Brook et al. 2014; Jones 2018; Martin et al. 2019; Morgan 2012). It could be argued that these access considerations are explored elsewhere on the web pages of other departments such as Accommodation, Students' Union, Libraries and other professional services. However, if an applicant was not aware of principles such as Universal Design for Learning (UDL), ${ }^{5}$ or the notion that inclusive education is the responsibility of all stakeholders within the institution (Kikabhai 2018; Wray 2018), they may perceive that the only elements of provision that they could access fully were academic and financial.

Hurst (2017) identifies seven principles that are central to the success of disabled students' experience when accessing higher education. These comprise access to information, peer support, accommodation, technical support, personal support, accessible environment and transport. It is interesting that most of these areas scored very low in this research, with an overwhelming emphasis on the academic experience.

\section{Erasure of disabled presence}

The concept-driven coding frame made it possible to recognise the lack of certain components across the sample, as well as the prominence of others. Disabled students' voices and contributions were significantly under-repre- 
sented across the web pages. Figure 2 shows that there were 63 examples of disabled students' voices in the authorship of web pages, and 65 visual representations of disability, including 36 disabled figures (11 per cent of the figures across the sample). This is significantly outweighed by the vast majority of information authored by parties other than disabled staff or students, with 359 pieces of information intended for parties other than disabled students (including staff, non-medical helpers and assessors).

The lack of representation of disabled students is of particular interest when it is noted that the key aims of the Strategic Equality Plans of several Welsh universities are to increase the visual representation of disability and address the under-representation of learners from protected groups. A recent European initiative (AHEAD 'Licence to Learn'), which advocates principles of UDL, includes in its baseline statements the question 'Are you using the expert knowledge of the diverse learner?' and highlights the centrality of this knowledge (UDLL Partnership 2017). Aspen Lillywhite and Gregor Wolbring (2019) cite this lack of acknowledgement of disabled students as 'knowledge producers' in their own research. They recognise that academic knowledge and evidence about the social situation of disabled students that could inform policy is missing. This lack of representation is a significant concern and could correlate with a similar lack of representation of disabled staff in higher education (Brown and Leigh 2018, 2020; Hurst 2017; Jeffress 2018; Lillywhite and Wolbring 2019). There is a wide lack of representation of disabled teachers (Lepkowska 2012; Meijer 2018; Riddell and Weedon 2014), and the Department for Education (2017) reported that only 0.5 per cent of the teaching workforce they consulted identified as disabled. The underrepresentation of disabled professionals in other disciplines (Baumberg et al. 2015) further exemplifies the lack of affirmative representation of disability in society.

The absence of disabled representation could be further allied to Parsons' (1964) vision of the 'sick role', whereby the right to exemption from everyday obligations is matched by an obligation to retreat from everyday life, so as to protect the 'system' from 'motivational contagion' as well as 'biological infection'. Taylor and Shallish (2019) echo the need to examine the absence of disabled bodies in higher education along with the extent of the normalised presence of non-disabled bodies. This unreflective acceptance of presence as well as the lack of questioning of absence are critical and may offer a tangible or relatable starting point to discussions about challenging ableism in higher education. 
A further critical consideration is Robert McRuer's (2016) construct of compulsory able-bodiedness, which Taylor and Shallish (2019) recognised in their field work. They report that the provision of closed captioning ${ }^{6}$ in real time at their university soon became a spectacle, which highlighted that the wider university community only perceived inclusion to be achieved through the hyper-visibility of non-conforming bodies. Following on from this, it may not be necessary for university web pages to make visible representations of disabled bodies in order to acknowledge or celebrate disabled students' success in higher education. However, the lack of incidental references to available provision, including note-takers, interpreters, assistive technology and accessible spaces, suggests that these experiences are not part of the norms of higher education pedagogy and culture.

\section{Disability advantage}

The considerable emphasis on the Medical/Individual Model or the deficitbased narrative (666 statements) over thinking informed by the Social Model of Disability (358 statements) demonstrates a lack of consideration of the value that disabled students bring to the institution. Rachel Heydon and Luigi Iannacci (2008) term the latter model an asset-oriented interpretation of disability, where the student is both valued and seen as valuable. There is an overwhelming emphasis in this data on disability being a deficient, deviation from the norm and something for which significant accommodation and arrangements will need to be made. This stance ignores the wider potential of non-normative ways of being and knowing (Hehir 2002; Iannacci 2018; Kliewer et al. 2006; Pickard 2019b) to enable disabled students to engage with academia and to bring great diversity and insight to the institution and future workforce (Accenture 2018; Eide and Eide 2011; EY 2019). As Janet Hargreaves and Lizzie Walker say (2014: 1749): 'A diverse workforce reflects the population it serves', and thus provides deep insight and knowledge not otherwise accessible. The university community should reflect the diversity of the workforce and of society, and yet exclusionary practices as well as these implicit messages ensure that disability continues to be seen as a deficit and thus not valued in academia.

There were 156 statements that demonstrated an affirmative stance towards disability, acknowledging the potential value and strengths that disabled students bring to higher education. For example, one source suggested diagnostic assessment was valuable to understand students' individual 
strengths. This source highlighted that dyslexic students likely have a very individual mix of strengths that will be an advantage in their studies, while openly acknowledging that difficulties arise because dyslexic people operate in a society in which communication has developed to privilege and 'to suit the non-dyslexic majority'. These pockets, which were largely found within the data set of an individual institution, offer examples of good practice for the sector to draw from, and could be a starting point from which to reconceptualise the wider sector's attitudes and beliefs about disability. Ways of moving towards these more positive interpretations of disability will be outlined in subsequent sections.

\section{Responding to the findings}

Since language choices are not necessarily representative of good practice and cannot affect change alone, the solution to challenging the deficit-based interpretations outlined in these web pages and the policies to which they align requires a call to action. Iannacci describes this as 'enacting inclusion' (2018: ix), while Emily Hutcheon and Gregor Wolbring (2012) offer first steps in challenging such ableist findings in practice. Another potential active response is drawn from Angharad Beckett's (2015) vision for anti-oppressive or anti-disablist education in the UK primary education sector, drawing from the principles of Kevin Kumashiro's (2000) typologies.

Kumashiro (2000) outlines four ways in which education has the potential to be inclusive: education for the other; education about the other; education that is critical of privileging and othering; and education that changes students and society. It is proposed that the model perpetuated across Welsh universities' Disability Service web pages currently emphasises education for the other (Kumashiro 2000 cited in Beckett and Buckner 2012). It lacks a consideration of the other three critical typologies. Exploration of these other typologies of anti-oppressive education could be a recommendation for challenging ableist practices, as is echoed by Iannacci (2018), Hurst (2017), Lydia Brown (2014) and Thomas Hehir (2002), amongst others. It is encouraging to note such approaches outlined in the Strategic Equality Plans of several of the universities in the sample; however, these intentions need to be enacted to affect real change. 


\section{Implications of this study}

While the legal connotations of both proactively fulfilling the duties of the Equality Act 2010 (Equality and Human Rights Commission 2014) and the expectations of the CMA (2015) are noted in this study, which also provides realistic information about what the DSA can offer, it is suggested that universities could both provide a better offer and develop better provision for disabled students through holistic pedagogical, marketing and other policy and strategy decisions.

If institutions further embedded the principles of UDL, as advocated by Nicola Martin and colleagues (2019), this would diminish reliance on specialist provision to an extent, and Disability Services' specialist knowledge could be redirected to enable academics to increase the accessibility of their general provision. As advocated by Mike Wray (2018) in Figure 1, provision could be reconceptualised to reallocate precious resources in a model that would enable the general offer to be more inclusive and limit the impact of diminishing DSA funds to support specialist intervention. As Martin and colleagues suggest: 'A combination of . . . DSA-funded adjustments where necessary, and with minimal bureaucracy, and an underpinning UDL approach to learning is advocated' (2019: 4). Inclusion, acceptance and provision for disabled students in the mainstream classroom offers a significant message about the conception and attitude an institution has towards disability and where they place the responsibility for addressing disabling barriers (Devlin and Pothier 2006).

There are examples of excellent practice amongst this sample, as well as further examples within these institutions which are not represented in the sources consulted. Looking more widely at the higher education sector across the United Kingdom, there are further examples of innovative and exciting approaches to inclusive and equitable practice that can be learnt from. However, Taylor and Shallish propose that the continued marginalisation of disabled students throughout the academy is 'not arbitrary, unintended, or accidental, but rather tied to the maintenance of able-bodied/minded supremacy' (2019: 3). This strongly worded assertion chimes with the attitudes of many other Critical Disability Studies scholars, activists and allies, who recognise the exclusionary practices of academia as intentional and inherently ableist. Lauren Hamilton terms these 'habitual misunderstandings and attitudinal barriers which serve to reflect historic and ableist assumptions of disability' (2019: 1018). Navin Kikabhai concurs that 'disability is 


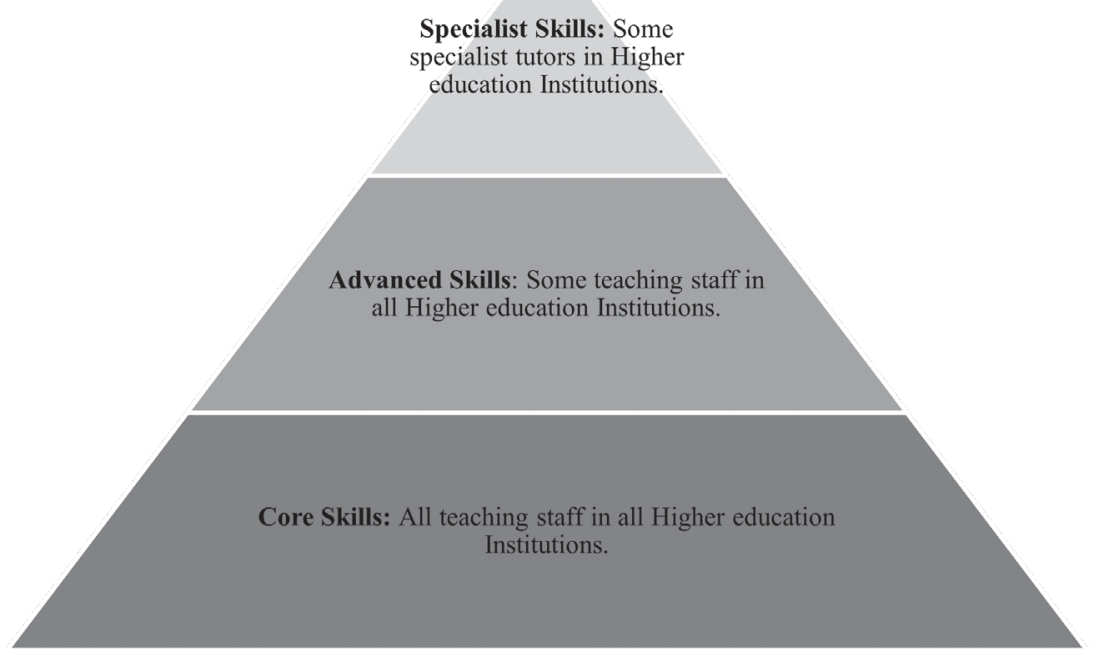

Figure 1. Provision reconceptualised (Wray [2018], adapted from Rose [2009])

intentionally shaped to legitimise processes of exclusion' (2018: 1). Through their research on the disability policies of the University of Victoria, Canada, Richard Devlin and Dianne Pothier conclude that current policy 'is not based on questioning of what is regular or typical, or of the privilege attached to what is regular or typical' (2006: 204). Rather, policy avoids the challenging critique of ableist practices at a systemic level.

To this end, higher education could be considered a bio-meritocracy defined as 'hierarchical social arrangements that are determined by those considered superior in mental ability, strength, health, memory or intellect' (Ojakangas 2016: 19). Dean Spade terms this deliberate and conscious exclusion 'administrative violence': 'The administrative systems themselves traumatize and disable us the most by disturbing life chances and promoting certain ways of life at the expense of others, all the while operating under regimes that declare universal equality' (2015: 103). This view aligns with testimonial and epistemic injustice which ensures the erasure of disabled students in academic spaces and negates the potential for celebrating a disability advantage. There is clearly significant work to be done to challenge ableist attitudes and practices (Hamilton 2019; Kikabhai 2018) and to undo or 'unlearn' ableism (Baglieri and Lalvani 2019) in Welsh higher education. 
Genuinely inclusive practice in higher education 'necessitates . . . equity considerations being embedded within all functions of the institution and treated as an ongoing process of quality enhancement. Making a shift of such magnitude requires cultural and systemic change at both the policy and practice levels' (Wray 2013: 4). This cultural and systemic shift is the responsibility of stakeholders at all levels within the institution and should not be a burden placed on the disabled student (Woods 2017). As John Richardson advocates, 'it is premature to consider widening participation in terms of access to [a] higher education until this is matched by parity in terms of educational outcomes' (2008: 33).

\section{Conclusion}

While the limitations of this study have been acknowledged, a comprehensive Qualitative Content Analysis of Welsh universities' Disability Service web pages has been conducted. The findings highlight a significant emphasis on deficit-based perspectives about disability in Welsh higher education, and a lack of disabled students' voices and presence was noted across the sample. This is attributed to testimonial injustice, whereby the credibility of disabled students' testimony is challenged and they are denied the social status of knowers. Disabled students are consistently portrayed as being in need of help and support in order to thrive in Welsh higher education. The over-emphasis on the necessity of achieving supposed independence echoes a post-humanist critique of the humanist ideals of independence and autonomy (Braidotti 2013; Goodley et al. 2014). The emphasis on disabled students requiring help to thrive is creating a binary distinction between nondisabled, independent students and disabled, dependent students which is not accurate to life as a student in Welsh higher education in the twenty-first century. Pedagogical approaches that would challenge these misconceptions have been explored which could benefit many students, whether they identify as disabled or not.

The sample web pages primarily focus on academic support and financial considerations, with little discussion about enabling access and participation in cultural or social activities that are widely acknowledged to be central to the student experience (Brook et al. 2014; Jones 2018; Martin et al. 2019; Morgan 2012). The focus of the web pages is overwhelmingly on the classroom experience, or activities relating to it, which mirrors what DSA will fund. Diana Katovitch (2009) suggests that 90 per cent of higher education 
students' time is in fact spent outside of the classroom. Research studies consulting disabled students about the provision they require, desire and receive in higher education identify some good practice regarding academic support (Sarrett 2018). Concurrently, many articles report on the challenges, complexity and delays of securing academic support (Busby 2019; Cai and Richdale 2016; Hannam-Swain 2018; Lillywhite and Wolbring 2019; McLean 2019; Riddell and Weedon 2014), as well as the need for more holistic provision (Sarrett 2018). The erasure of disabled students' presence and insights negates the potential to celebrate the value and expertise that disabled students bring to the institution, and the sector, and subsequently to the workforce and to society.

This article poses a challenge to the self-advocacy model of student success (Osborne 2019), positing that the under-representation of disabled students in higher education could be the result of a system of power relations operating holistically. The portrayal of disabled students may well limit the number of students who feel empowered to apply to university and give an implicit message about the value of disabled students to the institution. The burden of challenging this power imbalance is presented to the Welsh and UK-wide higher education sector, including stakeholders from recruitment, marketing, administration and academia, 'shifting the imbalanced burden of adapting away from [disabled] individuals' (Woods 2017: 1094). As Brown rightly states:

Few outside the disability community ever consider the consequences of their perceptions and limited understanding of disability, and many whose views are shaped by unsound and dangerous ideas continue to perpetuate ableism without ever having their privilege challenged and examined. Disability exists because we are largely complacent in allowing ourselves and our society to perpetuate a world where disabled people are marginalized and oppressed by attitudinal and systemic barriers to access. (Brown 2014: 44)

Fricker concurs by noting that 'social power is a capacity we have as social agents to influence how things go in the social world' (2007: 9). While the individual authors of each page or policy on the universities' web pages surely did not intend to exclude or demotivate disabled students, the collective power of the institutions and the sector to convey a message about disability as deficiency has the power to limit the number of applications, successful applications or successful completion of university courses. These 
web pages may have wider implications for applicants' confidence, identity and well-being. As social agents with privilege and power, it is the responsibility of all in academia to challenge this discourse and to take action to correct the epistemic ignorance (Kuokkanen 2008) which is causing this under-representation and undervaluing of disabled students in higher education and to shift the focus from a needs-based to a rights-based discourse for disabled students (Beauchamp-Pryor 2007, 2013).

\section{Acknowledgements}

Special thanks to Bonnie, a talented student whose departure from higher education highlighted to me that something sorely needed to change.

Beth Pickard is a Senior Lecturer and Researcher at the University of South Wales. Her music therapy practice is aligned with an affirmative interpretation of disability, informed by her research in Critical Disability Studies. Beth's research explores how disability is socially constructed, interpreted and represented across disciplines and pedagogy. E-mail: beth.pickard@southwales.ac.uk

\section{Notes}

1. The term 'disabled students' is used intentionally to acknowledge that students are actively disabled by barriers faced in their environment and the systems around them, as suggested by the Social Model of Disability (Barnes 2012; Goodley 2017). This is the preferred terminology of the Disability Rights Movement in Wales and in the United Kingdom (Shakespeare 2013), and there is an increasing challenge to person-first language in this context and a shift towards identity-first language more globally (Ladau 2014). I acknowledge this positioning as a non-disabled academic, and respects individuals' language choices.

2. The universities within the sample called their equivalent service by many different names, including 'Disability Service', 'Disability Support', 'Disability Office', 'Services for Disabled Students', 'Inclusion Service' and 'Accessibility Service'. The equivalent department was sought which provided information and services to disabled students for the purposes of this research study. This is the intended meaning of the phrase 'Disability Service' when used henceforth in this article. 
3. During the process of data collection, there were several live chat options inviting engagement and dialogue with the various university pages. Further research may be necessary to understand response rates and quality of responses to disabled applicants' questions to give further and deeper context to this area of investigation, since this function of dialogue and discussion was prominent on several sites and did not form part of this analysis.

4. The Welsh Assembly Government (2013) offers a clear statement: 'Firstly, all references to disabled people should use language which is consistent with the Social Model of Disability. "Disabled person" or "disabled people" is the appropriate way of describing people with impairments who are disabled by society. "People with disabilities" should not be used . . . Using the right language is important because it ensures the correct understanding of the issues'.

5. UDL is 'an approach based on planning for a diverse university community, rather than being surprised by diversity and attempting to retrofit adjustments for people who do not conform to the mythical norm stereotype' (Martin et al. 2019: 3). This approach is increasing in its recognition and application, and disrupts the notion that disabled students need individual adjustments or that the lecturer should not consider accessibility until a disabled student engages with the provision. The responsibility for the accessibility of the provision is proactively shifted to the institution under the philosophy of UDL. In using Baker's depiction of disability as 'whatever an institution seems not set up to "handle" and throws back on to the recipient' (2002: 696), UDL could significantly reduce the 'problem' of disability by addressing many of the systemic, disabling barriers posed by the institution before they are experienced by or 'thrown back' to students.

6. Closed captioning is the practice of including subtitles on any audio-visual content, primarily for learners who have hearing impairments or who are D/deaf. However, according to the principles of UDL listed above, this practice increases the accessibility of the provision for many learners, including learners for whom English is not their first language, for visual learners, and for others who may wish to clarify any wording or spelling.

\section{References}

Abreu, M., A. Hillier, A. Frye and J. Goldstein (2016), 'Student experiences utilizing disability support services in a university setting', College Student Journal 50, no. 3: 323-328. https://eric.ed.gov/?id = EJ1112130.

Accenture (2018), 'Getting equal: The disability inclusion advantage'. https://www .accenture.com/_acnmedia/pdf-89/accenture-disability-inclusion-research-report.pdf (accessed 8 August 2019).

Advance HE (2019), 'Athena SWAN Charter'. https://www.ecu.ac.uk/equality-charters/ athena-swan/ (accessed 18 February 2019).

Aitken, Z., L. Krnjacki, A. M. Kavanagh, A. D. LaMontagne and A. Milner (2017), 'Does social support modify the effect of disability acquisition on mental health? A longitudinal study of Australian adults', Social Psychiatry and Psychiatric Epidemiology 52, no. 10: 1247-1255. https://doi.org/10.1007/s00127-017-1418-5. 
Anastasiou, D. and J. M. Kauffman (2013), 'The social model of disability: Dichotomy between impairment and disability', Journal of Medical Philosophy 38, no. 4: 441-459. https://doi.org/10.1093/jmp/jht026.

Baglieri, S. and P. Lalvani (2019), Undoing Ableism (New York: Routledge).

Baglieri, S. and A. Shapiro (2017), Disability Studies and the Inclusive Classroom (2nd ed.) (New York: Routledge).

Baker, B. (2002), 'The hunt for disability: The new eugenics and the normalization of school children', Teachers College Record 104, no. 4: 663-703. https://doi.org/ 10.1111/1467-9620.00175.

Barnes, C. (2003), 'What a difference a decade makes: Reflecting on doing "emancipatory" disability research', Disability \& Society 18, no. 1: 3-17.

Barnes, C. (2012), 'Understanding the social model of disability: Past, present and future', in N. Watson, A. Roulstone and C. Thomas (eds), Routledge Handbook of Disability Studies, (London: Routledge), 12-29.

Barton, L. (1994), 'Disability, difference and the politics of definition', Australian Disability Review 3, no. 94: 8-22.

Baumberg, B., M. Jones and V. Wass (2015), 'Disability prevalance and disability-related employment gaps in the UK 1998-2012: Different trends in different surveys?' Social Science \& Medicine 141: 72-81. https://doi.org/10.1016/j.socscimed.2015.07.012.

Beauchamp-Pryor, K. (2007), A Framework for the Equality and Inclusion of Disabled Students in Higher Education (PhD Diss., Swansea University).

Beauchamp-Pryor, K. (2013), Disabled Students in Welsh Higher Education: A Framework for Equality and Inclusion (Rotterdam, Netherlands: Sense Publishers).

Beckett, A. (2015), 'Anti-oppressive pedagogy and disability: Possibilities and challenges', Scandinavian Journal of Disability Research 17, no. 1: 76-94. https://doi.org/10.1080/ 15017419.2013.835278.

Beckett, A. and L. Buckner (2012), 'Promoting positive attitudes towards disabled people: Definition of, rationale and prospects for anti-disablist education', British Journal of Sociology of Education 33, no. 6: 873-891. https://doi.org/10.1080/01425692 .2012.692046.

Berg, L. A., T. Jirikowic, K. Haerling and G. MacDonald (2017), 'Centennial Topics-Navigating the hidden curriculum of higher education for postsecondary students with intellectual disabilities', American Journal of Occupational Therapy 71, no. 3: 1-9. https://doi.org/ 10.5014/ajot.2017.024703.

Bolt, D. (2019), Cultural Disability Studies in Education: Interdisciplinary Navigations of the Normative Divide (London: Routledge).

Bolt, D. and C. Penketh (eds) (2016), Disability, Avoidance and the Academy: Challenging Resistance (London: Routledge).

Braidotti, R. (2013), The Posthuman (Malden, MA: Polity Press). 
BERA (British Educational Research Association) (2018), Ethical Guidelines for Educational Research, Fourth Edition. https://www.bera.ac.uk/publication/ethical-guidelines-foreducational-research-2018-online (accessed 10 October 2019).

British Psychological Society (2017), 'Ethics Guidelines for Internet-Mediated Research'. https://www.bps.org.uk/news-and-policy/ethics-guidelines-internet-mediatedresearch-2017 (accessed 10 October 2019).

Brook, H., D. Fergie, M. Maeorg and D. Michell (eds) (2014), Universities in Transition: Foregrounding Social Contexts of Knowledge in the First Year Experience (Adelaide, Australia: University of Adelaide Press).

Brown, L. X. Z. (2014), 'Disability in an ableist world', in C. Wood (ed.), Criptiques (San Bernardino, CA: May Day Publishing), 37-46.

Brown, N. and J. Leigh (2018), 'Ableism in academia: Where are the disabled and ill academics?' Disability \& Society 33, no. 6: 985-989. https://doi.org/10.1080/ 09687599.2018.1455627.

Brown, N. and J. Leigh (eds) (2020), Ableism in Academia: Theorising Experiences of Disability and Chronic Illness in Higher Education. (London: UCL Press).

Bryan, W. V. (2013), 'Struggle for freedom: Disability rights movements', in M. Adams, W. J. Blumfeld, C. Castaneda, H. W. Hackman, M. L. Peters and X. Suniga (eds), Readings for Diversity and Social Justice (3rd ed.) (New York: Routledge), 468-474.

Busby, E. (2019), 'Lack of support in universities drives deaf students to consider leaving degrees', Independent, 8 June. https://www.independent.co.uk/news/education/ education-news/deaf-students-university-support-national-deaf-childrens-societydisability-degrees-a8949266.html.

Burr, V. (2015), Social Constructionism (3rd ed.) (East Sussex, UK: Routledge).

Butterwick, C. (2019), 'I couldn't have gone to university without support for my disability', The Guardian, 24 January. https://www.theguardian.com/ education/2019/jan/24/i-couldnt-have-gone-to-university-without-support-for-mydisability? $\mathrm{CMP}=$ share_btn_tw.

Cai, R. Y. and A. L. Richdale (2016), 'Educational experiences and needs of higher education students with autism spectrum disorder', Journal of Autism and Developmental Disorders 46: 31-41. https://doi.org/10.1007/s10803-015-2535-1.

Campbell, F. (2000), 'Eugenics in a different key? New technologies and the "conundrum" of "disability", in M. Crotty, J. Germov and G. Rodwell (eds), A Race for a Place: Eugenics, Darwinism, and Social Thought and Practice in Australia (Newcastle, AU: University of Newcastle Press), 307-318.

CMA (Competition and Markets Authority) (2015), UK higher education providers-Advice on Consumer Protection Law, CMA33. https://www.gov.uk/government/collections/ higher-education-consumer-law-advice-for-providers-and-students (accessed 9 August 2019). 
Cunnah, W. (2015). 'Disabled students: Identity, inclusion and work-based placements', Disability \& Society 30, no. 2: 213-226. https://doi.org/10.1080/09687599.2014 .996282 .

Denzin, N. K. and Y. S. Lincoln (2017), The Sage Handbook of Qualitative Research (5th ed.) (Thousand Oaks, CA: SAGE).

Department for Education (2017), School Workforce in England: November 2016 (Sheffield, UK: Department for Education. https://assets.publishing.service.gov.uk/ government/uploads/system/uploads/attachment_data/file/620825/SFR25_2017_ MainText.pdf (accessed 8 September 2019).

Department for Work and Pensions (2018), 'Disability confident employer scheme and guidance'. https://www.gov.uk/government/collections/disability-confident-campaign (accessed 18 February 2019).

Devlin, R. F. and D. Pothier (2006), Critical Disability Theory: Essays in Philosophy, Politics, Policy, and Law (Vancouver: University of British Columbia Press).

Dobson, S. (2019), 'A documentary analysis of the support services offered to adult learners with dyslexia in higher education', Journal of Further and Higher Education 43, no. 9: 1181-1195. https://doi.org/10.1080/0309877X.2018.1463359.

Dolmage, J. T. (2017), Academic Ableism: Disability and Higher Education (Ann Arbor: University of Michigan Press).

Eide, B. L. and F. F. Eide (2011), The Dyslexic Advantage: Unlocking the Hidden Potential of the Dyslexic Brain (London: Hay House).

Ellis, K., R. Garland-Thomson, M. Kent and R. Robertson (eds) (2019), Manifestos for the Future of Critical Disability Studies: Volume 1 (Interdisciplinary Disability Studies) (New York: Routledge).

Equality Act (2010), Section 149 (London: HMSO).

Equality and Human Rights Commission (2014), Equality Act 2010: Technical Guidance on Further and Higher Education (London: Equality and Human Rights Commission).

Evans, N. J., E. M. Broido, K. R. Brown and A. K. Wilke (2017), Disability in Higher Education: A Social Justice Approach (San Francisco: Jossey-Bass).

EY (2019), The Value of Dyslexia Report: Dyslexic Strengths and the Changing World of Work. http://madebydyslexia.org/assets/downloads/EY-the-value-of-dyslexia.pdf (accessed 8 September 2019).

Fox Keller, E. (1992), 'Nature, nurture, and the human genome project', in D. Kevles and L. Hood (eds), The Code of Codes (Cambridge, MA: Harvard University Press), 281-299.

Fricker, M. (2007), Epistemic Injustice: Power and the Ethics of Knowing (Oxford: Oxford University Press).

Gibson, S. (2012), 'Narrative accounts of university education: Socio-cultural perspectives of students with disabilities', Disability \& Society 27, no. 3: 353-369. https://doi.org/ 10.1080/09687599.2012.654987. 
Goodley, D. (2017), Disability Studies: An Interdisciplinary Introduction (2nd ed.) (London: SAGE).

Goodley, D., R. Lawthom and K. Runswick-Cole (2014), 'Posthuman Disability Studies', Subjectivity 7, no. 4: 342-361. https://doi.org/10.1057/sub.2014.15.

Griful-Freixenet, J., K. Struyven, M. Verstichele and C. Andries (2017), 'Higher education students with disabilities speaking out: Perceived barriers and opportunities of the universal design for learning framework', Disability \& Society 32, no. 10: 1627-1649. https://doi.org/10.1080/09687599.2017.1365695.

Groeben, N. and R. Rustemeyer (1994), 'On the integration of quantitative and qualitative methodological paradigms (based on the example of content analysis)', in I. Borg and P. Mohler (eds), Trends and Perspectives in Empirical Social Research (Berlin: De Gruyter), 308-326.

Hacking, I. (1995), 'The looping effects of human kinds', in D. Sperber, P. Premack and A. J. Premack (eds), Causal Cognition: A Multidisciplinary Debate (Oxford: Clarendon Press), 351-394.

Hamilton, L. (2019), 'The rhetoric of widening participation in higher education: Ending the barriers against disabled people', Disability \& Society 34, no. 6: 1018-1019. https://doi.org/10.1080/09687599.2019.1603914.

Hannam-Swain S. (2018), 'The additional labour of a disabled PhD student', Disability \& Society 33, no. 1: 138-142. https://doi.org/10.1080/09687599.2017.1375698.

Hargreaves, J. and L. Walker (2014), 'Preparing disabled students for professional practice: Managing risk through a principles-based approach', Journal of Advanced Nursing 70, no. 8: 1748-1757. https://doi.org/10.1111/jan.12368.

Harraway, D. (1988), 'Situated knowledges: The science question in feminism and the privilege of partial perspective', Feminist Studies 14, no. 3: 575-599. https://doi.org/ $10.2307 / 3178066$.

Harraway, D. (1996), 'Situated knowledges: The science question in feminism and the privilege of partial perspective', in E. F. Keller and H. E. Longino (eds), Feminism and Science (Oxford: Oxford University Press), 235-248.

Hehir, T. (2002), 'Eliminating ableism in education', Harvard Educational Review 72, no. 2: 1-32. https://doi.org/10.17763/haer.72.1.03866528702g2105.

HESA (Higher Education Statistics Agency) (2018), 'HE student enrolments by personal characteristics 2013/14 to 2017/18'. https://www.hesa.ac.uk/data-and-analysis/ sb252/figure-4\# (accessed 19 February 2019).

Heydon, R. and L. Iannacci (2008), Early Childhood Curricula and the De-Pathologizing of Childhood (Toronto: University of Toronto Press).

Hjörne, E. and R. Säljö (2014), 'Representing diversity in education: Student identities in contexts of learning and instruction', International Journal of Educational Research 63: 1-4. https://doi.org/10.1016/j.ijer.2012.10.001. 
Hong, B. S. S. (2015), 'Qualitative analysis of the barriers college students with disabilities experience in higher education', Journal of College Student Development 56, no. 3: 209-226. https://doi.org/10.1353/csd.2015.0032.

Hurst, A. (2017), 'Reflecting on researching in higher education', in L. Barton (ed), Disability and Society: Emerging Issues and Insights (London: Routledge), 123-146.

Hutcheon, E. J. and G. Wolbring (2012), 'Voices of “disabled” post-secondary students: Examining higher education "disability” policy using an ableism lens', Journal of Diversity in Higher Education 5, no. 1: 39-49. https://doi.org/10.1037/a0027002.

Iannacci, L. (2018), Reconceptualizing Disability in Education (Lanham, MD: Lexington Books).

Jeffress, M. (ed.) (2018), International Perspectives on Teaching with Disability: Overcoming Obstacles and Enriching Lives (London: Routledge).

Johnson, C., H. Rossiter, B. Cartmell, M. Domingos and S. Svanaes (2019), Evaluation of Disabled Students' Allowances (DSAs) (London: Department for Education). https:// www.gov.uk/government/publications/evaluation-of-disabled-students-allowancesdsas (accessed 8 February 2019).

Jones, R. (2018), 'The student experience of undergraduate students: Towards a conceptual framework', Journal of Further and Higher Education 42, no. 8: 1040-1054. https://doi.org/10.1080/0309877X.2017.1349882.

Katovitch, D. M. (2009), The Power to Spring up: Postsecondary Education Opportunities for Students with Significant Disabilities (Bethesda, MD: Woodbine House).

Kendall, L. (2016), 'Higher education and disability: Exploring student experiences', Cogent Education 3, no. 1: 1-12. https://doi.org 10.1080/2331186X.2016.1256142.

Kerschbaum, S. L., L. T. Eisenman and J. M. Jones (eds) (2017), Negotiating Disability: Disclosure and Higher Education (Ann Arbor: University of Michigan Press).

Kidd, I. J., J. Medina and G. Pohlhaus (eds) (2017), The Routledge Handbook of Epistemic Injustice (London: Routledge).

Kikabhai, N. (2018), The Rhetoric of Widening Participation in Higher Education: Ending the Barriers against Disabled People (Cham, Switzerland: Palgrave Macmillan).

Kirby, J. (2009), 'Paradox and conflicting identities in disability service provision in higher education: A personal reflection', Journal of Inclusive Practice in Further and Higher Education 2, no. 1: 70-81.

Kliewer, C., D. Biklen and C. Kasa-Hendrickson (2006), 'Who may be literate? Disability and cultural resistance to the cultural denial of competence', American Educational Research Journal 43, no. 2: 163-167. https://doi.org/10.3102/00028312043002163.

Kumari Campbell, F. (2009), Contours of Ableism: The Production of Disability and Abledness (Basingstoke, UK: Palgrave Macmillan).

Kumashiro, K. K. (2000), 'Toward a theory of anti-oppressive education', Review of Educational Research 70, no. 1: 25-53. https://doi.org/10.3102/00346543070001025. 
Kuokkanen, R. (2008), 'What is hospitality in the academy? Epistemic ignorance and the (im)possible gift', Review of Education, Pedagogy and Cultural Studies 30, no. 1: 60-82. https://doi.org/10.1080/10714410701821297.

Ladau, E. (2014), 'What should you call me? I get to decide: Why I'll never identify with person-first language', in C. Wood (ed.), Criptiques (San Bernardino, CA: May Day Publishing), 47-56.

Lepkowska, D. (2012), 'Where are the disabled teachers?' The Guardian, 12 November. https://www.theguardian.com/education/2012/nov/12/disabled-not-encouraged -teacher-training-costs.

Liasidou, A. (2014) 'Critical disability studies and socially just change in higher education', British Journal of Special Education 42, no. 2: 120-135. https://doi.org/ 0.1111/1467-8578.12063.

Lillywhite, A. and G. Wolbring (2019), 'Undergraduate disabled students as knowledge producers including researchers: A missed topic in academic literature', Education Sciences 9, no. 259: 1-22. https://doi.org/ 10.3390/edusci9040259.

Martin, N., M. Wray, A. James, E. A. Draffan, J. Krupa and P. Turner (2019), Implementing Inclusive Teaching and Learning in UK Higher Education: Utilising Universal Design for Learning (UDL) as a Route to Excellence (London: Society for Research into Higher Education). https://www.srhe.ac.uk/downloads/reports-2017/Nicola-Martin-SRHE -Research-Report.pdf (accessed8 September 2019).

Matrix (2018), 'About the standard'. https://matrixstandard.com/about-the-standard/ (accessed 21 February 2019).

McGregor, K. K., N. Langenfeld, S. Van Horne, J. Oleson, M. Anson and W. Jacobson (2016), 'The university experiences of students with learning disabilities', Learning Disabilities Research \& Practice 31, no. 2: 90-102. https://doi.org/10.1111/ldrp.12102.

McLean, M. (2019), 'Getting serious about the barriers facing disabled students', WONKE, 28 June. https://wonkhe.com/blogs/getting-serious-about-the-barriers -facing-disabled-students/.

McRuer, R. (2016), 'Compulsory able-bodiedness and queer/disabled existence’, in L. J. Davis (ed.), The Disability Studies Reader (5th ed.), (London: Routledge), 369-378.

Meijer, C. (2018), 'Music education should be inclusive, so where are the disabled teachers?' The Guardian, 13 April. https://www.theguardian.com/teacher-network/2018/apr/ 13/music-education-should-be-inclusive-so-where-are-the-disabled-teachers.

Mitchell, D. T. (2016), 'Disability, diversity, and diversion: Normalization and avoidance in higher education', in D. Bolt and C. Penketh (eds), Disability, Avoidance and the Academy: Challenging Resistance (London: Routledge), 9-20.

Morgan, M. (2012), Improving the Student Experience: A Practical Guide for Universities and Colleges (Abingdon, UK: Routledge).

Myers, K. A., J. Jenkins Lindburg and D. M. Nied (2014), 'Allies for inclusion: Disability and equity in higher education', ASHE Higher Education Report 39, no. 5: 1-132. https://doi.org/10.1002/aehe.20011. 
Nunan, T., R. George and H. McCausland (2005), 'Inclusive education in universities: Why it is important and how it might be achieved', in K. Topping and S. Mahoney (eds), The Routledge Falmer Reader in Inclusive Education (London: Routledge), 250-260.

Ojakangas, Mika (2016), On the Greek Origins of Biopolitics: A Reinterpretation of the Origins of Biopower (New York: Routledge).

Oliver, M. (2017), 'A sociology of disability or a disablist sociology?' in L. Barton (ed.), Disability \& Society: Emerging Issues and Insights (London: Routledge), 18-42.

Osborne, T. (2019), 'Not lazy, not faking it: Teaching and learning experiences of university students with disabilities', Disability \& Society 34, no. 2: 228-252. https://doi.org/ 10.1080/09687599.2018.1515724.

Parsons, T. (1951), The Social System (London: Routledge).

Parsons, T. (1964), Social Structure and Personality (Glencoe, IL: Free Press).

Pickard, B. (2019a), 'Demystifying the process of engaging with the disability and dyslexia service in higher education', Journal of Inclusive Practice in Further and Higher Education 10, no. 1: 40-58. https://core.ac.uk/display/227097406.

Pickard, B. (2019b), 'Valuing neurodiversity: A humanistic, non-normative model of music therapy exploring Rogers' person-centred approach with young adults with autism spectrum conditions', in H. Dunn, E. Coombes, E. Maclean, H. Mottram and J. Nugent (eds), Music Therapy and Autism across the Lifespan: A Spectrum of Approaches (London: Jessica Kingsley Publishers), 297-330.

Pickard, B. and V. Norris (2018), 'Disability service: The process for exploring support', Unpublished Infographic, University of South Wales.

Rapley, M. (2010), The Social Construction of Intellectual Disability (Cambridge: Cambridge University Press).

Redpath, J., P. Kearney, P. Nicholl, M. Mulvenna, J. Wallace and S. Martin (2013), 'A qualitative study of the lived experiences of disabled post-transition students in higher education institutions in Northern Ireland', Studies in Higher Education 38, no. 9: 1334-1350. https://doi.org/10.1080/03075079.2011.622746.

Richardson, J. (2008), 'The attainment of ethnic minority students in UK higher education', Studies in Higher Education 33, no. 1: 33-48. https://doi.org/10.1080/ 03075070701794783.

Riddell, S. and E. Weedon (2014), 'Disabled students in higher education: Discourses of disability and the negotiation of identity', International Journal of Educational Research 63: 38-46. https://doi.org/10.1016/j.ijer.2013.02.2008.

Riddell, S., T. Tinklin and A. Wilson (2007), Disabled Students in Higher Education (New York: Routledge).

Roberts, P. and E. Hou (2016), 'The best education money can buy? Disabled university students and the Equality Act 2010', International Journal of Discrimination and the Law 16, no. 2-3: 143-160. https://doi.org/10.1177/1358229116655651. 
Rose, J. (2009), Independent Review of the Primary Curriculum (Nottingham, UK: DCSF).

Sarrett, J. (2018), 'Autism and accommodations in higher education: Insights From the autism community', Journal of Autism and Developmental Disorders 48, no. 3: 679-693. https://doi.org/ 10.1007/s10803-017-3353-4.

Scambler, S. (2012), 'Long-term disabling conditions and disability theory', in N. Watson, A. Roulstone and C. Thomas (eds), Routledge Handbook of Disability Studies (New York: Routledge), 136-150.

Schreier, M. (2012), Qualitative Content Analysis in Practice (London: SAGE).

Seale, J., J. Georgeson, C. Mamas and J. Swain (2015), 'Not the right kind of "digital capital"? An examination of the complex relationship between disabled students, their technologies and higher education institutions', Computers \& Education 82: 118-128. https://doi.org/ 10.1016/j.compedu.2014.11.007.

Shakespeare, T. (2013), Disability Rights and Wrongs Revisited (London: Routledge).

Spade, D. (2015), Normal Life: Administrative Violence, Critical Trans Politics, and the Limits of Law (Durham, NC: Duke University Press).

Steyaert, J. (2005), 'Web-based higher education, the inclusion/exclusion paradox', Journal of Technology in Human Services 23, no. 1-2: 67-78. https://doi.org/10.1300/ J017v023n01_05.

Stone, E. and M. Priestley (1996), 'Parasites, pawns and partners: Disability research and the role of non-disabled researchers', British Journal of Sociology 47, no. 4: 699-716. https://doi.org/ 10.2307/591081.

Stramondo, J. A. (2010), 'How an ideology of pity is a social harm to people with disabilities', Social Philosophy Today 26: 121-134. https://doi.org/10.5840/ socphiltoday20102610.

Taylor, A. and L. Shallish (2019), 'The logic of bio-meritocracy in the promotion of higher education equity', Disability \& Society 34, no. 7-8: 1200-1223. https://doi.org/ 10.1080/09687599.2019.1613962.

Taylor, M. J., Y. Turnbull, J. Bleasdale, H. Francis and H. Forsyth (2017), 'Transforming support for students with disabilities in UK higher education', Support for Learning 31, no. 4: 367-384. https://doi.org/10.1111/1467-9604.12143.

Thomas, C. (2007), Sociologies of Disability, 'Impairment', and Chronic Illness: Ideas in Disability Studies and Medical Sociology (London: Palgrave).

Tremain, S. (2017), 'Knowing disability, differently’, in I. J. Kidd, J. Medina and G. Pohlhaus (eds), The Routledge Handbook of Epistemic Injustice (London: Routledge), 175-183.

Tuana, N. (2006), 'The speculum of ignorance: The Women's Health Movement and epistemologies of ignorance', Hypatia 21, no. 3: 1-19. https://doi.org/10.1353/ hyp.2006.0037.

UDLL Partnership (2017), Universal Design for Learning: A Best Practice Guideline (Trondheim, Norway: Universell). 
UN General Assembly (2006), Convention on the Rights of Persons with Disabilities: Resolution Adopted by the General Assembly, 24 January 2007. A/RES/61/106, https:// www.refworld.org/docid/45f973632.html.

Varul, M. Z. (2010), 'Talcott Parsons, the sick role and chronic illness', Body \& Society 16, no. 2: 72-94. https://doi.org/10.1177/1357034X10364766.

Vickerman, P. and M. Blundell (2010), 'Hearing the voices of disabled students in higher education', Disability \& Society 25, no. 1: 21-32. https://doi.org/10.1080/ 09687590903363290.

Watson, N. (2012), 'Researching disablement', in N. Watson, A. Roulstone and C. Thomas (eds), Routledge Handbook of Disability Studies (New York: Routledge), 93-105.

Welsh Assembly Government (2013), 'The Social Model'. https://gov.wales/topics/peopleand-communities/equality-diversity/rightsequality/disability/socialmodel/?lang = en (accessed 19 February 2019).

Welsh Assembly Government (2017), A Review of the Disabled Students' Allowances. http:// gov.wales/statistics-and-research/review-disabled-students-allowances/?lang = en (accessed 4 April 2018).

Wendell, S. (1996), The Rejected Body: Feminist Philosophical Reflections on Disability (New York: Routledge).

Woods, R. (2017), 'Exploring how the social model of disability can be re-invigorated for autism: In response to Jonathan Levitt', Disability \& Society 32, no. 7: 1090-1095. https://doi.org/10.1080/09687599.2017.1328157.

Wray, M. (2013), Developing an Inclusive Culture in Higher Education: Final Report (York: Higher Education Academy).

Wray, M. (2018), 'Re-visioning support for disabled students in HE', WONKE, 25 June, https://wonkhe.com/blogs/re-visioning-support-for-disabled-students-in-he/ (accessed 27 June 2019). 